African Crop Science Journal by African Crop Science Society is licensed under a Creative Commons Attribution 3.0 Uganda License. Based on a work at www.ajol.info/ and www.bioline.org.br/cs DOI: https://dx.doi.org/10.4314/acsj.v27i1.5

\title{
COMBINING ABILITY FOR GRAIN YIELD AND SILKING OF MAIZE INBRED LINES DERIVED FROM THREE OPEN POLLINATED VARIETIES RELEASED FOR MID ALTITUDES OF RWANDA: COMPARISON OF DIALLEL AND NORTH CAROLINA DESIGN II
}

\author{
C. NGABOYISONGA, F. NIZEYIMANA, M.K. GAFISHI, T. NDAYISHIMIYE, \\ J.D. MBARUSHIMANA, J. NYIRABASHYITSI, P. MUTANYAGWA and A. NYOMBAYIRE \\ Rwanda Agriculture and Animal Resources Development Board, P. O. Box 5016 Kigali, Rwanda \\ Corresponding author: c.ngaboyisonga@ rab.gov.rw, c.ngaboyisonga@yahoo.com
}

(Received 13 April, 2018; accepted 27 February, 2019)

\begin{abstract}
Maize (Zea mays L.) cropping systems have undergone extraordinary development in Rwanda during the past ten years, mainly due to the increase of agriculture productivity by the Crop Intensification Program (CIP). Consequently, there has been a shift from varieties from Open Pollinated Varieties (OPVs) to hybrid cultivars. The objective of this study was to estimate the general and specific combining abilities of inbred lines, developed from three OPVs released in mid-altitudes of Rwanda. Seventeen inbred lines were divided into female and male groups, and crossed using the North Carolina Design II (NCDII); while ten of them were crossed using Griffing's Diallel Method 4 (GDM4). The resulting crosses were evaluated at Cyabayaga, Rubona and Bugarama in Rwanda from October 2015 to March 2016. Results showed that additive and non-additive effects controlled grain yield, but non-additive effects were predominant whereas additive and maternal effects predominantly controlled silking. Six inbred lines (RML0006, RML0014, RML0015, RML0018, RM0017 and RML0010) had high general combining abilities (GCAs) for grain yield and negligible GCAs for silking; whereas ten crosses had specific combining abilities (SCAs) superior to $1.5 \mathrm{t} \mathrm{ha}^{-1}$ for grain yield and negligible SCAs for silking. These six inbred lines will also be used to predict and form maize synthetic varieties; while the ten crosses with best SCAs will be utilised for the developing maize hybrid varieties with high yields and reduced silking time.
\end{abstract}

Key Words: Additive effects, general combining ability, maternal effects, non-additive effects, specific combing ability

\section{RESUME}

Le développement de la culture du maïs (Zea mays L.) au Rwanda a connu un essor extraordinaire pendant les dix dernières années principalement à cause de l'augmentation de la productivité agricole par le Programme d'Intensification des Cultures (CIP). Ce développement a été accompagné par des changements de type de variété, des Variétés à Pollinisation Ouverte (OPVs) vers les hybrides. L'objectif 
cette étude était l'estimation des aptitudes générales et spécifiques à la combinaison des lignées de maïs développées dans trois OPVs adaptées aux moyennes altitudes. Dix-sept lignées ont été divisées en deux groupes : le groupe des parents femelles et males. Puis, elles ont été crossées suivant 'North Carolina Design II' (NCDII). Ensuite, dix lignées choisies ont été crossées suivant le diallèle de Griffing,

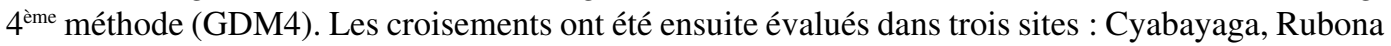
et Bugarama de Décembre 2015 jusqu'en Mars 2016. Les observations ont porté sur les rendements en grains and le temps de floraison femelle. Les résultats ont montré que le rendement en grains était contrôlé par les effets additifs et non-additifs des gènes, mais les effets non-additifs étaient dominants alors que la floraison femelle était essentiellement contrôlée par les effets additifs et maternels. Six lignées (RML0006, RML0014, RML0015, RML0018, RM0017 and RML0010) ont eu les hautes aptitudes générales à la combinaison (GCAs) pour le rendement en grains et les GCAs négligeables pour le temps de floraison femelle alors que dix croisements ont eu les aptitudes spécifiques à la combinaison (SCAs) supérieures à $1,5 \mathrm{tha}^{-1}$ pour le rendement en grains et les SCAs négligeables pour la floraison femelle. Les lignées avec les meilleures GCAs vont être utilisées à la formation des variétés synthétiques alors les croisements avec les meilleures SCAs vont être utilisés au développement des variétés hybrides de maïs avec un haut rendement et une période de floraison femelle réduite.

Mots Clés : Aptitude générale à la combinaison, aptitude spécifique à la combinaison, effets additifs, effets maternels, effets non-additifs

\section{INTRODUCTION}

Rwanda's maize (Zea mays L.) cropping systems have undergone unprecedented transformational development over the past 10 years, with the national production revolving from $97,251 \mathrm{t}$ in 2005 and $667,833 \mathrm{t}$ in 2013 (FAO, 2017). The most significant factor behind this expansion was the advent of the Crop Intensification Program (CIP) in 2007 (Nahayo et al., 2016) which ushered in land consolidation and use of inputs (fertilisers, pesticides, seeds) on seven selected crops: maize, rice, wheat, beans, soybean, Irish potato and cassava.

The expansion of maize cropping systems has prompted changes in maize variety requirement and research objectives where the focus has shifted from Open Pollinated Varieties (OPVs) to hybrid cultivars, with the best performing hybrid varieties being identified through the study of combining abilities. The combining abilities are commonly studied through the mating designs, with the most popular being diallel, North Carolina Designs II (NCDII) and Line $\times$ Tester (Hallauer et al., 2010; Fasahat et al., 2016).
Diallel designs involve crossing all the parents in all possible combinations, both direct and reciprocal crosses, hence, resulting in four types of diallel crossing designs. The first, called complete diallel, involves the parents, direct and reciprocal crosses; the second includes the parents and direct crosses; and the third contains direct and reciprocal crosses; while the fourth called half diallel comprises only direct crosses (Chukwu et al., 2016). Griffing (1956) provided the analysis of the four types of diallel and called them Method I, Method II, Method III and Method IV, respectively.

The North Carolina Design II (NCDII) mating design, also called factorial design, was developed and described by Camstock and Robinson (1952). NCDII involves grouping the parents into two sets; namely, male and female parents and crossing every member of male group to every member of the female group, giving a cross-classification design (Fasahat et al., 2016). Although its basic features are different from those of diallel, the genetic information obtained from the two designs is similar. In diallel, the same parents are used as males and females; whereas in NCDII, 
different sets of parents are used as males and females giving a factorial design. For both diallel and NCDII, the number of crosses increases with the number of parents included; although, the number of crosses is considerably less for the NCDII (Hallauer et al., 2010).

Two important assumptions, fixed versus random models, about the parents are considered for both diallel and NCDII before crosses are produced and evaluated in replicated trials. The fixed model (model I) is considered when the parents are the reference populations; whereas the random model (model II) is considered when parents are taken as a random sample of genotypes from a reference population.

The major difference between the two models lies in the objective of crossing. For model I, the aim is to estimate the effects of each pair of parents for specific crosses and for all crosses that include a common parent. For the model II, the goal is to estimate components of variance (Mason et al., 2003; Shalabh, 2009). However, each model has particular weaknesses. In model I, estimated effects are applicable only for the parents included and would be different from parents crossed with a different group of parents. In model II, the estimation of component of variance requires a large number of parents and the model assumes the absence of epistasis (Hallauer et al., 2010).

The four Griffing's diallels methods have so far been extensively used in several studies involving model I as well model II on maize crop, for estimating the combining abilities of parents for use in hybrid development (Karaya et al., 2009; Devi and Singh, 2011; Gakunga et al., 2012; Cabral et al., 2015; Al-Naggar et $a l ., 2016)$ or estimating the components of variance (Technow et al., 2012; Chukwu et al., 2016; Nardino et al., 2016; Oliveira et al., 2016) of key agronomic traits. Furthermore, they have been widely applied to other crops such as rice, wheat and potato (Asfaliza et al., 2012; Kumar et al., 2017; Terres et al., 2017). Moreover, the NCDII has been utilised to estimate both combing abilities and components of variance (Ngaboyisonga et al., 2008; Khattab et al., 2011; Narayanamma et al., 2013; Salami and Ogbowuro, 2016). Furthermore, the NCDII have been utilised on other crops for various genetic studies.

The line $x$ tester design is a variant of NCDII where a series of line are crossed to a number of testers giving cross-classification designs. The analysis of variance and the estimation of combining abilities are performed in the same way as NCDII (Hallauer et al., 2010; Fasahat et al., 2016). The line $\times$ test designs are mainly used for maize crop to classify the inbred lines into heterotic patterns or to eliminate inbred lines in early generations of inbred line development that have not perform well in testcross performance (Kamara et al., 2014; Assefa et al., 2017).

The objective of the present study was to (i) estimate GCAs and SCAs of inbred lines developed from released Open Pollinated Varieties (OPVs) for mid altitudes of Rwanda and (ii) select inbred lines and crosses exhibiting best combing abilities for future utilisation in hybrid variety development programme.

\section{MATERIALS AND METHODS}

Seventeen maize inbred lines (Table 1) were developed using the pedigree methodology as described by Hallauer et al. (2010) from three Open Pollinated Varieties (OPVs): Kigega, Ndaruhutse and ISARM101 released for mid altitudes of Rwanda from September 2010 to June 2014 at Cyabayaga (Nyagatare) Research Station. Variety Kigega was derived from the CIMMYT population ZM607; while Ndaruhutse was developed from the CIMMYT Pool 32 as described by Ngaboyisonga (2003).

Variety ISARM101 was developed using CIMMYT germplasm and local ecotypes as described by Ngaboyisonga et al. (2014). Firstly, ten parental inbred lines were chosen and crossed in GDM4 methodology to produce 45 Single Cross Hybrids (SCHs). Secondly, all the seventeen inbred lines were divided into 
TABLE 1. Pedigrees of the parent inbred maize lines used in a combining ability study in Rwanda

\begin{tabular}{|c|c|c|c|c|}
\hline No & $\begin{array}{l}\text { Names of } \\
\text { inbred lines }\end{array}$ & Pedigrees & $\begin{array}{l}\text { Source of } \\
\text { germplam }\end{array}$ & $\begin{array}{c}\text { Open Pollinated } \\
\text { Variety }\end{array}$ \\
\hline 1 & RML0002+* & KIG-79-1-1-B*4-\# & ZM607 & Kigega \\
\hline 2 & $\mathrm{RMLO003}^{+*}$ & KIG-38-1-1-B*4-\# & ZM607 & Kigega \\
\hline 3 & RML0004+* & KIG-34-2-1-B*4-\# & ZM607 & Kigega \\
\hline 4 & $\mathrm{RMLO005}^{+}$ & KIG-80-4-1-B*4-\# & ZM607 & Kigega \\
\hline 5 & RML0006 ${ }^{\hat{\mathrm{A}}^{*}}$ & NDA-70-2-1-B*4-\# & Pool32 & Ndaruhutse \\
\hline 6 & RML0007Â & NDA-76-1-1-B*4-\# & Pool32 & Ndaruhutse \\
\hline 7 & RML0008Â & NDA-76-3-1-B*4-\# & Pool32 & Ndaruhutse \\
\hline 8 & RML0009 $9^{\hat{\mathrm{A}}^{*}}$ & NDA-17-1-1-B*4-\# & Pool32 & Ndaruhutse \\
\hline 9 & RML0010 $\hat{\mathrm{A}}^{*}$ & NDA-76-2-1-B*4-\# & Pool32 & Ndaruhutse \\
\hline 10 & RML0011 $\hat{A}$ & NDA-6-3-1-B*4-\# & Pool32 & Ndaruhutse \\
\hline 11 & RML0012令 & NDA-11-4-1-B*4-\# & Pool32 & Ndaruhutse \\
\hline 12 & RML0013 $3^{\hat{A}^{*}}$ & NDA-6-1-1-B*B-\# & Pool32 & Ndaruhutse \\
\hline 13 & $\mathrm{RML} 0014^{+*}$ & M101-27-1-5-6-2-3-B & Pop. Nya. & ISARM101 \\
\hline 14 & RML0015 ${ }^{+*}$ & M101-41-2-2-7-7-1-B & Pop. Nya. & ISARM101 \\
\hline 15 & $\mathrm{RMLO017}^{+}$ & M101-41-2-2-7-7-5-B & Pop. Nya. & ISARM101 \\
\hline 16 & RML0018+* & M101-64-1-4-27-5-3-B & Pop. Nya. & ISARM101 \\
\hline 17 & RML0019+ & KIG-38-4-1-B*4-\# & ZM607 & Kigega \\
\hline
\end{tabular}

+: Used as female parent in North Carolina Design. Â: Used as male parent in North Carolina Design II

*: Used in Griffing's diallel method 4 design

two groups: a group of nine female parents and a group of eight male parents. The male parents were generated from Ndaruhutse (Pool32); whereas the female parents were developed from Kigega (ZM607) and ISARM101. They were crossed in NCDII fashion to produce $72 \mathrm{SCH}$.

The crossing for both GMD4 and NCDII was conducted from September 2014 to July 2015 at Cyabayaga Research Station. For the GMD4, one parent was planted side-by-side with another parent, and pollination was manually done by depositing pollen from one parent on the silks of the other parent and viceversa, and bulking the seed obtained at harvest. For NCDII, each female parent was planted side-by-side with each male parent, and manual pollination was achieved by depositing pollen from the male parent on the silks of the female parent.

The seed of the cross was obtained from the female parent. The $45 \mathrm{SCH}$ formed using
GMD4 were evaluated at three sites; namely Cyabayaga, Rubona and Bugarama (Table 2) from October 2015 to March 2016. The 72 SCHs generated using NCDII were evaluated at Cyabayaga and Rubona, only during the same period.

The experimental design used in each site was alpha-lattice $(0,1)$, with three replications. They were analysed as Randomised Complete Block Design (RCBD); with three replications. A plot was made up of two rows of 5-m length, with a distance between rows of $0.75 \mathrm{~m}$ and a distance between hills of $0.25 \mathrm{~m}$. Two grains were planted per hill, followed by thinning to one plant per hill, at three weeks after sowing.

Mineral fertilisers were applied at rates of $51 \mathrm{~kg} \mathrm{ha}^{-1} \mathrm{~N}, 51 \mathrm{~kg} \mathrm{ha}^{-1} \mathrm{P}_{2} \mathrm{O}_{5}$ and $51 \mathrm{~kg} \mathrm{ha}^{-1}$ K2O before planting, using NPK (17-17-17), at a rate of $300 \mathrm{~kg} \mathrm{ha}^{-1}$. Six weeks after planting, $46 \mathrm{~kg} \mathrm{ha}^{-1} \mathrm{~N}$ (46-0-0) were applied at a rate of $100 \mathrm{~kg} \mathrm{ha}^{-1}$ using urea. This study 
was rain-fed; while weeding was performed, as was needed.

Grain yield at $15 \%$ grain moisture content and silking in days from planting to $50 \%$ silk emergence were the agronomic traits recorded. Grain yields at $15 \%$ grain moisture content were obtained by the formula:

$\mathrm{GY}=10 \times \frac{\mathrm{FW}}{\mathrm{Ax}(\mathrm{B}+\mathrm{C}) \times \mathrm{D}} \times \frac{100-\mathrm{GM}}{100-15} \times \frac{\mathrm{GW}}{\mathrm{DW}}$

In this formula, fresh weight in (FW) was obtained by weighing the total number of ears harvested in a plot. At the same time, a sample of kernels was taken in the middle of ten selected ears and was used to determine the grain moisture in \% (GM) of the same plot, using the portable moisture-meter Mini-GAC® (DICKEY-john, 2017). Thereafter, the dry weight in $\mathrm{kg}(\mathrm{DW})$ was obtained by sun drying all the ears harvested in the same plot and the grain weight in $\mathrm{kg}(\mathrm{GW})$ after shelling all ears. " $A$ " was the distance in $m$ between rows, " $B$ " the distance in $m$ between hills at planting, " $C$ " the length of harvested rows in $\mathrm{m}$, and $\mathrm{D}$ the number of rows harvested. Silking was recorded in days after planting by considering the number of days from planting to when silks emerged out of ears in $50 \%$ of plants in a plot (approximately 21 plants).

The GMD4 was analysed by considering fixed effects, following the procedures of Zhang and Kang (1997, 2003) and Zhang et al. (2005), using SAS computer package, 9.4 edition (SAS Institute Inc., 2011). The NCDII was analysed following a factorial model as described by Mason et al. (2003) and Shalabh (2009), by considering fixed effects as well and using the GenStat computer package, 14 edition (Payne et al., 2011).

The NCDII was analysed following a factorial model as described by Mason et al. (2003) and Shalabh (2009), by considering fixed effects as well and using the GenStat computer package, 14 edition (Payne et al., 2011). The comparison of additive effects and non-additive effects was achieved by the ratio 
64

$\mathrm{F}=\frac{\mathrm{MS}_{\mathrm{GCA}}}{\mathrm{MS}_{\mathrm{SCA}}}=\frac{\mathrm{GCA}}{\mathrm{SCA}} \quad$ in $\mathrm{GDM} 4$ and $\mathrm{F}=\frac{\mathrm{MS}_{\mathrm{FP}}}{\mathrm{MS}_{\mathrm{MP}}}=\frac{\mathrm{GCA}_{\mathrm{FP}}}{\mathrm{GCA}_{\mathrm{MP}}}$ in NCDII whereas the significance of maternal effects in NCDII was estimated by the ratio $\mathrm{F}=\frac{\mathrm{MS}_{\mathrm{FP}}}{\mathrm{MS}_{\mathrm{MP}}}=\frac{\mathrm{GCA}_{\mathrm{FP}}}{\mathrm{GCA}_{\mathrm{MP}}}$.

\section{RESULTS}

Griffing'diallel method 4. The combined analysis of variance across the three sites: Cyabayaga, Rubona and Bugarama showed significant differences between sites for both grain yield and silking $(\mathrm{P}=0.001)$ (Table 3$)$. Furthermore, it showed significant differences between crosses for grain yield $(\mathrm{P}=0.001)$ and silking $(\mathrm{P}=0.01)$; implying the presence of general and or specific combining abilities for the two traits. Additionally, the interaction of sites by crosses was significant for grain yield $(\mathrm{P}=0.001)$ and silking $(\mathrm{P}=0.01)$, indicating the presence of interaction of sites by general and specific combing abilities (Table 3). Moreover, the ratio between $\mathrm{GCA}$ and $\mathrm{SCA} F=0.76$ for grain yield was not significant $(\mathrm{P}>0.05)$; while for silking, the $\mathrm{F}=3.15$ was significant at $\mathrm{p}=0.01\left(\mathrm{~F}_{(9,35)}\right.$ from distribution tables equal to 2.16 at $\mathrm{P}=0.05,2.96$ at $\mathrm{P}=0.01$ and 4.18 at $\mathrm{P}=0.001)$.

The combined analysis of variance further indicated that the GCA was significant for both grain yield and silking $(\mathrm{P}=0.001)$; while the $\mathrm{SCA}$ was significant for grain yield $(\mathrm{P}=0.001)$; but not significant for silking $(\mathrm{P}>0.05)$. Moreover, interactions, site $\times$ GCA and site $\times$ SCA were significant for both grain yield $(\mathrm{P}=0.001)$ and silking $(\mathrm{P}=0.01)$ (Table 3$)$.

The parent inbred lines RML0018, RML0015 and RML0006, had positive (0.29, 0.26 and $\left.0.24 \mathrm{t} \mathrm{ha}^{-1}\right)$ and significant GCA $(\mathrm{P}=0.05)$ for grain yield, and negative GCA ($0.88 \mathrm{~d},-0.55 \mathrm{~d}, 0.34 \mathrm{~d}$ ) or non-significant $(\mathrm{P}=0.001, \mathrm{P}=0.05$ and $\mathrm{P}>0.05) \mathrm{GCA}$ for silking. Line RML0014 had the highest GCA of $0.44 \mathrm{t} \mathrm{ha}^{-1}$ for grain yield. Nevertheless, it had a positive $(0.66 \mathrm{~d})$ and significant $(\mathrm{P}=0.01)$ GCA for silking (Table 4).

Crosses RML0004/RML0010 and RML0010/RML0013 had positive and significant $(\mathrm{P}=0.001)$ SCAs for grain yield

TABLE 3. Analysis of variance of Griffing's diallel method 4 with ten inbred maize lines for grain yield and silking

\begin{tabular}{|c|c|c|c|c|c|c|c|}
\hline \multirow[t]{2}{*}{ Sources of variation } & \multirow[t]{2}{*}{$\mathrm{DF}$} & \multicolumn{3}{|c|}{ Grain yield } & \multicolumn{3}{|c|}{ Silking } \\
\hline & & SS & MS & $\mathrm{F}$ & SS & MS & $\mathrm{F}$ \\
\hline Treatments & 140 & 1208.9 & 8.6 & $10.2^{* * *}$ & 3679.8 & 26.3 & $6.6^{* * *}$ \\
\hline Sites & 2 & 555.9 & 277.9 & $329.0^{* * * *}$ & 2664 & 1332.0 & $334.7^{* * * *}$ \\
\hline Sites/replications & 6 & 8.9 & 1.5 & $1.8^{\mathrm{NS}}$ & 174.1 & 29.0 & $7.3^{\text {*** }}$ \\
\hline Crosses & 44 & 343.3 & 7.8 & $9.2^{* * *}$ & 291.9 & 6.6 & $1.7^{* *}$ \\
\hline GCA & 9 & 55.8 & 6.2 & $7.3^{* * *}$ & 130.6 & 14.5 & $3.7^{* * * *}$ \\
\hline $\mathrm{SCA}$ & 35 & 287.5 & 8.2 & $9.7^{* * *}$ & 161.3 & 4.6 & $1.2^{\mathrm{NS}}$ \\
\hline Sites $\times$ crosses & 88 & 300.8 & 3.4 & $4.1^{* * *}$ & 549.7 & 6.2 & $1.6^{* *}$ \\
\hline GCA $\times$ sites & 18 & 83.6 & 4.6 & $5.5^{* * *}$ & 164.4 & 9.1 & $2.8^{* *}$ \\
\hline SCA $\times$ sites & 70 & 258.8 & 3.7 & $3.3^{* * *}$ & 385.4 & 5.5 & $1.6^{* *}$ \\
\hline Error & 264 & 1050.6 & 4.0 & - & 1050.6 & 4.0 & - \\
\hline
\end{tabular}

$* * *=$ Significant at $\mathrm{P}=0.001 ; * *=$ Significant at $\mathrm{P}=0.01 ; *=$ Significant at $\mathrm{P}=0.05 ; \mathrm{NS}=$ Not significant $(\mathrm{P}>0.05)$ 
TABLE 4. General combining abilities for grain yield and silking of ten inbred maize lines in Griffing's diallel, method 4

\begin{tabular}{|c|c|c|c|c|c|c|}
\hline \multirow[t]{2}{*}{ Parents } & \multicolumn{3}{|c|}{ Grain yield } & \multicolumn{3}{|c|}{ Silking } \\
\hline & GCA & SE & $\mathrm{t}$ & GCA & SE & $\mathrm{t}$ \\
\hline RML0002 & -0.41 & 0.10 & $-3.95^{* * *}$ & -0.31 & 0.22 & $-1.41^{\mathrm{NS}}$ \\
\hline RML0003 & -0.49 & 0.10 & $-3.85^{* * *}$ & 0.10 & 0.22 & $0.46^{\mathrm{NS}}$ \\
\hline RML0004 & 0.06 & 0.10 & $0.62^{\mathrm{NS}}$ & 0.26 & 0.22 & $1.15^{\mathrm{NS}}$ \\
\hline RML0018 & 0.29 & 0.10 & $2.84^{*}$ & -0.88 & 0.22 & $-3.96^{* * *}$ \\
\hline RML0014 & 0.44 & 0.10 & $4.33^{* * *}$ & 0.66 & 0.22 & $2.95^{* *}$ \\
\hline RML0015 & 0.26 & 0.10 & $2.00^{*}$ & -0.51 & 0.22 & $-2.28^{*}$ \\
\hline RML0006 & 0.24 & 0.10 & $1.94^{*}$ & 0.34 & 0.22 & $1.52^{\mathrm{NS}}$ \\
\hline RML0010 & -0.27 & 0.10 & $-2.64^{* *}$ & 0.19 & 0.22 & $0.83^{\mathrm{NS}}$ \\
\hline RML0009 & -0.11 & 0.10 & $-1.05^{\mathrm{NS}}$ & 0.13 & 0.22 & $0.59^{\mathrm{NS}}$ \\
\hline RML0013 & -0.02 & 0.10 & $-0.24^{\mathrm{NS}}$ & 0.03 & 0.22 & $0.15^{\mathrm{NS}}$ \\
\hline
\end{tabular}

$* * *=$ Significant at $\mathrm{P}=0.001 ; * *=$ Significant at $\mathrm{P}=0.01 ; *=$ Significant at $\mathrm{P}=0.05 ; \mathrm{NS}=$ Not significant $(\mathrm{P}>0.05)$

superior to $2.00 \mathrm{t} \mathrm{ha}^{-1}$. Crosses RML0002/ RML0015, RML0002/RML0015, RML0018/ RML0013 had positive and significant SCAs $(\mathrm{P}=0.001 ; \mathrm{P}=0.01)$ ranging between 1.50 and $2.00 \mathrm{t}$ ha 1 ; whereas the crosses RML0003/ RML0009 and RML0014/RML0010 had also positive and significant SCAs $(\mathrm{P}=0.001)$ of $1.55 \mathrm{t} \mathrm{ha}^{-1}$ and $1.09 \mathrm{t} \mathrm{ha}^{-1}$, respectively. All these crosses with high SCAs for grain yields had non-significant SCAs ( $\mathrm{P}>0.05)$ for silking, while very few crosses had significant SCAs for silking (Table 5).

North Carolina Design II. The combined analysis of variance across the two locations; Cyabayaga and Rubona revealed significant differences $(\mathrm{P}=0.001)$ between sites and crosses for grain yield and silking, implying presence of GCA and SCA for the two traits (Table 6). Furthermore, the differences between female and male parents were significant $(\mathrm{P}=0.001)$ indicating the significance of GCA for both female and male parents (Table 6). The ratio comparing GCA of female parents and GCA of male parents $\mathrm{F}=1.87$ for grain yield was not significant (ratio inferior to $\mathrm{F}_{(8,7)}=3.73$ at $\mathrm{P}=0.05$ from $\mathrm{F}$ distribution tables). On the contrary, the same ratio $F=4.01$ for silking was significant at $\mathrm{P}=0.05$ (ratio superior to $\mathrm{F}_{(8,7)}=3.73$ at $\mathrm{P}=0.05$ from $\mathrm{F}$ distribution tables).

The interaction sites $\times$ crosses was significant for grain yield $(\mathrm{P}=0.001)$; but not significant for silking ( $\mathrm{p}>0.005)$; suggesting that sites were interacting with GCA and SCA for grain yield, however, they did not interact for silking (Table 6). Furthermore, the ratio comparing GCA and SCA F=2.07 was not significant $(p>0.05)$ for grain yield (ratio inferior to $\mathrm{F}_{(7,56)}=2.18$ at $\mathrm{p}=0.05$ from the $\mathrm{F}$ distribution tables); while this proportion $\mathrm{F}=3.24$ was significant at $\mathrm{p}=0.01$ for silking (proportion superior to $\mathrm{F}_{(7,56)}=2.98$ at $\mathrm{p}=0.01$ but inferior to $\mathrm{F}_{(7,56)=} 4.13$ at $\mathrm{p}=0.001$ from the F distribution tables).

The female parent, RML0014, had the highest GCA of $1.40 \mathrm{t} \mathrm{ha}^{-1}$ for grain yield; although it had a positive and significant GCA $(\mathrm{P}=0.001)$ of 3.1 days for silking (Table 7$)$. Similarly, the female parent, RML0017 had a GCA of $1.00 \mathrm{t} \mathrm{ha}^{-1}$, but had a positive and significant GCA $(\mathrm{P}=0.05)$ for silking of 1.72 day. The male, parent RML0010, had a very 
TABLE 5. Specific combining abilities for grain yield and silking of 10 inbred maize lines in Griffing's diallel, method 4

\begin{tabular}{|c|c|c|c|c|c|c|}
\hline \multirow[t]{2}{*}{ No Crosses } & \multicolumn{3}{|c|}{ Grain yield } & \multicolumn{3}{|c|}{ Silking } \\
\hline & GCA & SE & $\mathrm{T}$ & GCA & SE & $\mathrm{t}$ \\
\hline RML0002/RML0003 & -0.16 & 0.27 & $-0.59^{\mathrm{NS}}$ & 0.27 & 0.59 & $0.45^{\mathrm{NS}}$ \\
\hline RML0002/RML0004 & -1.19 & 0.27 & $-4.41^{* * *}$ & 0.45 & 0.59 & $0.76^{\mathrm{NS}}$ \\
\hline RML0002/RML0018 & 0.55 & 0.27 & $2.02^{*}$ & -0.42 & 0.59 & $-0.71^{\mathrm{NS}}$ \\
\hline RML0002/RML0014 & -0.68 & 0.27 & $-2.53^{*}$ & -0.85 & 0.59 & $-1.44^{\mathrm{NS}}$ \\
\hline RML0002/RML0015 & 1.56 & 0.27 & $5.76^{* * *}$ & -0.46 & 0.59 & $-0.78^{\mathrm{NS}}$ \\
\hline RML0002/RML0006 & -0.24 & 0.27 & $-0.88^{\mathrm{NS}}$ & -0.64 & 0.59 & $-1.09^{\mathrm{NS}}$ \\
\hline RML0002/RML0010 & -0.43 & 0.27 & $-1.59^{\mathrm{NS}}$ & 1.52 & 0.59 & $2.58^{*}$ \\
\hline RML0002/RML0009 & -0.88 & 0.27 & $-3.24^{* *}$ & 0.02 & 0.59 & $0.03^{\mathrm{NS}}$ \\
\hline RML0002/RML0013 & 1.47 & 0.27 & $5.46^{* * *}$ & -0.75 & 0.59 & $-1.28^{\mathrm{NS}}$ \\
\hline RML0003/RML0004 & 0.31 & 0.27 & $1.14^{\mathrm{NS}}$ & 0.39 & 0.59 & $0.67^{\mathrm{NS}}$ \\
\hline RML0003/RML0018 & 1.55 & 0.27 & $5.75^{* * * *}$ & -0.37 & 0.59 & $-0.64^{\mathrm{NS}}$ \\
\hline RML0003/RML0014 & 0.59 & 0.27 & $2.17^{*}$ & 1.02 & 0.59 & $1.73^{\mathrm{NS}}$ \\
\hline RML0003/RML0015 & -1.25 & 0.27 & $-4.62^{* * *}$ & -0.28 & 0.59 & $-0.47^{\mathrm{NS}}$ \\
\hline RML0003/RML0006 & -0.53 & 0.27 & $-1.97^{*}$ & -0.12 & 0.59 & $-0.21^{\mathrm{NS}}$ \\
\hline RML0003/RML0010 & -1.29 & 0.27 & $-4.76^{* * *}$ & 0.38 & 0.59 & $0.64^{\mathrm{NS}}$ \\
\hline RML0003/RML0009 & 1.17 & 0.27 & $4.35^{* * *}$ & -0.10 & 0.59 & $-0.16^{\mathrm{NS}}$ \\
\hline RML0003/RML0013 & -0.40 & 0.27 & $-1.46^{\mathrm{NS}}$ & -0.64 & 0.59 & $-1.09^{\mathrm{NS}}$ \\
\hline RML0004/RML0018 & -0.25 & 0.27 & $-0.91^{\mathrm{NS}}$ & 0.08 & 0.59 & $0.14^{\mathrm{NS}}$ \\
\hline RML0004/RML0014 & -0.04 & 0.27 & $-0.14^{\mathrm{NS}}$ & -0.10 & 0.59 & $-0.16^{\mathrm{NS}}$ \\
\hline RML0004/RML0015 & -0.43 & 0.27 & $-1.60^{\mathrm{NS}}$ & -0.28 & 0.59 & $-0.47^{\mathrm{NS}}$ \\
\hline RML0004/RML0006 & 0.66 & 0.27 & $2.43^{*}$ & 0.22 & 0.59 & $0.38^{\mathrm{NS}}$ \\
\hline RML0004/RML0010 & 2.05 & 0.27 & $7.58^{* * *}$ & 1.06 & 0.59 & $1.80^{\mathrm{NS}}$ \\
\hline RML0004/RML0009 & 0.31 & 0.27 & $1.14^{\mathrm{NS}}$ & 0.78 & 0.59 & $1.33^{\mathrm{NS}}$ \\
\hline RML0004/RML0013 & -2.44 & 0.46 & $-5.28^{* * *}$ & 0.38 & 0.59 & $0.64^{\mathrm{NS}}$ \\
\hline RML0018/RML0014 & 0.11 & 0.27 & $0.39^{\mathrm{NS}}$ & -0.69 & 0.59 & $-1.18^{\mathrm{NS}}$ \\
\hline RML0018/RML0015 & 0.10 & 0.27 & $0.35^{\mathrm{NS}}$ & -1.19 & 0.59 & $-2.03^{*}$ \\
\hline RML0018/RML0006 & -0.25 & 0.27 & $-0.92^{\mathrm{NS}}$ & 0.35 & 0.59 & $0.59^{\mathrm{NS}}$ \\
\hline RML0018/RML0010 & -1.07 & 0.27 & $-3.97^{* * *}$ & 0.28 & 0.59 & $0.48^{\mathrm{NS}}$ \\
\hline RML0018/RML0009 & -0.70 & 0.27 & $-2.59^{*}$ & 0.21 & 0.59 & $0.36^{\mathrm{NS}}$ \\
\hline RML0018/RML0013 & 1.92 & 0.58 & $3.34^{* *}$ & -0.07 & 0.59 & $-0.12^{\mathrm{NS}}$ \\
\hline RML0014/RML0015 & -0.78 & 0.27 & $-2.90^{* *}$ & -0.78 & 0.59 & $-1.32^{\mathrm{NS}}$ \\
\hline RML0014/RML0006 & 0.37 & 0.27 & 1.38 & 0.38 & 0.59 & $0.64^{\mathrm{NS}}$ \\
\hline RML0014/RML0010 & 1.09 & 0.27 & $4.05^{* * *}$ & -1.01 & 0.59 & $-1.73^{\mathrm{NS}}$ \\
\hline RML0014/RML0009 & 0.15 & 0.27 & $0.55^{\mathrm{NS}}$ & -0.58 & 0.59 & $-0.99^{\mathrm{NS}}$ \\
\hline RML0014/RML0013 & -0.84 & 0.65 & $-1.29^{\mathrm{NS}}$ & 1.81 & 0.59 & $3.08^{* *}$ \\
\hline RML0015/RML0006 & 0.18 & 0.27 & $0.65^{\mathrm{NS}}$ & 0.11 & 0.59 & $0.19^{\mathrm{NS}}$ \\
\hline RML0015/RML0010 & 0.38 & 0.27 & $1.40^{\mathrm{NS}}$ & -0.53 & 0.59 & $-0.90^{\mathrm{NS}}$ \\
\hline RML0015/RML0009 & -0.71 & 0.27 & $-2.63^{* * *}$ & 1.28 & 1.00 & $1.27^{\mathrm{NS}}$ \\
\hline RML0015/RML0013 & 0.93 & 0.70 & $1.32^{\mathrm{NS}}$ & 0.25 & 1.25 & $0.20^{\mathrm{NS}}$ \\
\hline RML0006/RML0010 & 0.47 & 0.27 & $1.72^{\mathrm{NS}}$ & -1.25 & 1.41 & $-0.88^{\mathrm{NS}}$ \\
\hline RML0006/RML0009 & -0.49 & 0.27 & $-1.81^{\mathrm{NS}}$ & 0.58 & 1.53 & $0.38^{\mathrm{NS}}$ \\
\hline RML0006/RML0013 & 0.62 & 0.74 & $0.85^{\mathrm{NS}}$ & -1.28 & 1.60 & $-0.80^{\mathrm{NS}}$ \\
\hline RML0010/RML0009 & -1.40 & 0.39 & $-3.61^{* * *}$ & 0.18 & 0.84 & $0.22^{\mathrm{NS}}$ \\
\hline RML0010/RML0013 & 2.08 & 0.58 & $3.57^{* * *}$ & 2.34 & 1.26 & $1.86^{\mathrm{NS}}$ \\
\hline RML0009/RML0013 & -2.20 & 0.55 & $-3.97^{* * *}$ & -1.04 & 1.20 & $-0.86^{\mathrm{NS}}$ \\
\hline
\end{tabular}

$* * *=$ Significant at $\mathrm{P}=0.001 ; * *=$ Significant at $\mathrm{P}=0.01 ; *=$ Significant at $\mathrm{P}=0.05 ; \mathrm{NS}=$ Not significant $(\mathrm{P}>0.05)$ 
TABLE 6. Analysis of variance of North Carolina Design II $(9 \times 8)$ with nine female and eight male inbred maize lines for grain yield and silking

\begin{tabular}{lrrrrrrr}
\hline Sources of variation & DF & \multicolumn{1}{c}{ SS } & MS & \multicolumn{1}{c}{ F } & SS & MS & F \\
\hline Sites & 1 & 70.7 & 70.73 & $146.34^{* * *}$ & 13172.2 & 13172.19 & $2036.66^{* * *}$ \\
Sites/replications & 2 & 7.7 & 3.85 & $7.97^{* * *}$ & 233.7 & 116.86 & $18.07^{* * * *}$ \\
Crosses & 71 & 467.5 & 6.58 & $13.62^{* * *}$ & 3194.2 & 44.99 & $6.96^{* * *}$ \\
Female parents & 8 & 142.4 & 17.80 & $36.83^{* * *}$ & 1818.5 & 227.31 & $35.15^{* * * *}$ \\
Male parents & 7 & 66.6 & 9.52 & $19.70^{* * *}$ & 396.4 & 56.63 & $8.76^{* * *}$ \\
FP $\times$ MP & 56 & 258.4 & 4.61 & $9.55^{* * *}$ & 979.3 & 17.49 & $2.70^{* * *}$ \\
Sites $\times$ crosses & 71 & 172.5 & 2.43 & $5.03^{* * *}$ & 537.3 & 7.57 & $1.17^{\text {NS }}$ \\
Sites $\times$ female parents & 8 & 28.1 & 3.51 & $7.26^{* * *}$ & 77.3 & 9.67 & $1.49^{\text {NS }}$ \\
Sites $\times$ male parents & 7 & 10.7 & 1.53 & $3.17^{* * *}$ & 77.5 & 11.07 & $1.71^{\text {NS }}$ \\
Sites $\times$ FP $\times$ MP & 56 & 133.8 & 2.39 & $4.94^{* * *}$ & 382.5 & 6.83 & $1.06^{\text {NS }}$ \\
Residual & 142 & 68.6 & 0.48 & - & 918.4 & 6.47 & - \\
& & & & & & & - \\
Total & 287 & 787.1 & - & - & 18055.8 & - & - \\
\hline
\end{tabular}

$* * *=$ Significant at $\mathrm{P}=0.001 ; * *=$ Significant at $\mathrm{P}=0.01 ; *=$ Significant at $\mathrm{P}=0.05 ; \mathrm{NS}=$ Not significant $(\mathrm{P}>0.05)$

TABLE 7. General combining abilities for grain yield and silking of nine female and eight male inbred maize lines in North Carolina Design II $(9 \times 8)$

\begin{tabular}{|c|c|c|c|c|c|c|c|c|}
\hline Parents & No & Names & GCA & SE & $\mathrm{t}$ & GCA & SE & $\mathrm{t}$ \\
\hline \multirow[t]{9}{*}{ Female parents } & 1 & RML0019 & -0.42 & 0.56 & $-0.75^{\mathrm{NS}}$ & -1.74 & 0.59 & $-2.93^{*}$ \\
\hline & 2 & RML0002 & -0.44 & 0.33 & $-1.34^{\mathrm{NS}}$ & -0.93 & 0.99 & $-0.93^{\mathrm{NS}}$ \\
\hline & 3 & RML0003 & -0.61 & 0.45 & $-1.35^{\mathrm{NS}}$ & -1.52 & 0.94 & $-1.62^{\mathrm{NS}}$ \\
\hline & 4 & RML0005 & -0.47 & 0.30 & $-1.56^{\mathrm{NS}}$ & -1.46 & 0.43 & $-3.42^{* *}$ \\
\hline & 5 & RML0018 & 0.37 & 0.55 & $0.67^{\mathrm{NS}}$ & -2.46 & 1.08 & $-2.28^{*}$ \\
\hline & 6 & RML0014 & 1.40 & 0.34 & $4.06^{* *}$ & 3.10 & 1.01 & $3.08^{* *}$ \\
\hline & 7 & RML0004 & -0.56 & 0.19 & $-2.92^{*}$ & 5.14 & 0.86 & $5.96^{* * *}$ \\
\hline & 8 & RML0015 & -0.26 & 0.27 & $-0.97^{\mathrm{NS}}$ & -1.86 & 0.47 & $-3.97^{* *}$ \\
\hline & 9 & RML0017 & 1.00 & 0.44 & $2.26^{*}$ & 1.72 & 0.77 & $2.24^{*}$ \\
\hline \multirow[t]{8}{*}{ Male parents } & 1 & RML0006 & 0.08 & 0.35 & $0.23^{\mathrm{NS}}$ & 1.93 & 1.26 & $1.53^{*}$ \\
\hline & 2 & RML0007 & 0.05 & 0.43 & $0.12^{\mathrm{NS}}$ & 0.23 & 1.21 & $0.19^{\mathrm{NS}}$ \\
\hline & 3 & RML0008 & -0.48 & 0.33 & $-1.49^{\mathrm{NS}}$ & -1.99 & 1.04 & $-1.92^{*}$ \\
\hline & 4 & RML0009 & 0.07 & 0.45 & $0.17^{\mathrm{NS}}$ & -1.41 & 1.02 & $-1.38^{\mathrm{NS}}$ \\
\hline & 5 & RML0010 & 1.03 & 0.48 & $2.13^{*}$ & 0.32 & 1.18 & $0.27^{\mathrm{NS}}$ \\
\hline & 6 & RML0013 & 0.22 & 0.50 & $0.44^{\mathrm{NS}}$ & -0.41 & 0.79 & $-0.51^{\mathrm{NS}}$ \\
\hline & 7 & RML0011 & -0.57 & 0.34 & $-1.68^{\mathrm{NS}}$ & 0.95 & 1.17 & $0.81^{\mathrm{NS}}$ \\
\hline & 8 & RML0012 & -0.40 & 0.41 & $-0.97^{\mathrm{NS}}$ & 0.37 & 1.09 & $0.34^{\mathrm{NS}}$ \\
\hline
\end{tabular}

$* * *=$ Significant at $\mathrm{P}=0.001 ; * *=$ Significant at $\mathrm{P}=0.01 ; *=$ Significant at $\mathrm{P}=0.05 ; \mathrm{NS}=\mathrm{Not}$ significant $(\mathrm{P}>0.05)$ 
high GCA for grain yield of $1.03 \mathrm{t} \mathrm{ha}^{-1}$ and nonsignificant GCA $(\mathrm{P}>0.05)$ for silking (Table 7). Cross RML0019/RML0006 had the highest and significant SCA of $2.81 \mathrm{t} \mathrm{ha}^{-1}(\mathrm{P}=0.001)$ for grain yield (Table 8 ), and a negative and significant SCA $(-2.43 \mathrm{~d}, \mathrm{P}=0.05)$. Other crosses with GCAs superior to $2.00 \mathrm{t} \mathrm{ha}^{-1}$ and significant for grain yield and negative or nonsignificant SCA for silking included: RML0018/RML0013 (2.59 $\left.\mathrm{tha}^{-1}, \mathrm{P}=0.01\right)$ and RML0018/RML0009 (2.09 t ha-1, P=0.01). Crosses RML0017/RML0010, RML0015/ RML0008, RML0002/RML0012, RML0014/ RML0012 and RML0014/RML0007 had positive and significant SCAs between 1.00 and $2.00 \mathrm{tha}^{-1}$, and negative or non-significant SCAs. Crosses RML0003/RML0010, RML0019/RML0007 and RML0015/ RML0008 had significant SCAs comprised between 1.00 and $2.00 \mathrm{t} \mathrm{ha}^{-1}$; however, they had positive and significant SCAs for silking (Tables 8 and 9).

\section{Grifing'Diallel Method 4 (GDM4) versus} North Carolina Design II (NCDII)

The results of analysis showed, in the two designs GMD4 and NCDII, that GCA was significant $(\mathrm{P}=0.001)$ for grain yield and silking. Nevertheless, they showed that in the two designs, the SCA was significant $(\mathrm{P}=0.001)$ for grain yield, while it was not significant $(\mathrm{P}>0.05)$ for silking in GDM4 and significant $(\mathrm{P}=0.001)$ in NCDII (Tables 3 and 6).

The ratio $\mathrm{F}=\mathrm{GCA} / \mathrm{SCA}$ of 0.76 was inferior to one, hence, not significant for grain yield $(\mathrm{P}>0.05)$ in GMD4; but it was superior to one (3.24) and significant at $\mathrm{P}=0.01$ in NCDII. Moreover, the same ratio $\mathrm{F}=\mathrm{GCA} / \mathrm{SCA}$ (4.18 and 4.13) was significant for silking in both GDM4 and NCDII at $\mathrm{P}=0.001$. Besides, the interactions site $\times$ GCA and site $\times$ SCA were significant at $\mathrm{p}=0.001$ for grain yield and silking in GDM4, but they were not significant in NCDII (Tables 3 and 6).

The two designs GDM4 and NCDII identified the inbred line RML0014 with the highest GCA for grain yield, although the value of $0.44 \mathrm{t} \mathrm{ha}^{-1} \mathrm{~kg}$ in GDM4 was lower than the value of $1.40 \mathrm{t} \mathrm{ha}^{-1}$ in NCDII (Tables 4 and 7). In the same way, the two designs identified the cross RML0018/RML0013 with high SCA of $1.92 \mathrm{t} \mathrm{ha}^{-1}$ for GDM4 and $2.59 \mathrm{t} \mathrm{ha}^{-1}$ for NCDII.

TABLE 8. Specific combining abilities for grain yield of nine female and eight male inbred maize lines in North Carolina Design II $(9 \times 8)$

\begin{tabular}{lccllllll}
\hline Parents & RML & RML & RML & RML & RML & RML & RML \\
0006 & 0007 & 0008 & 0009 & 0010 & 0013 & $\begin{array}{c}\text { RML } \\
0011\end{array}$ \\
\hline RML0019 & $2.81^{* * *}$ & $1.63^{* * *}$ & $-0.1^{\mathrm{NS}}$ & $-1.05^{*}$ & $-1.11^{*}$ & $-0.16^{\mathrm{NS}}$ & $-1.48^{*}$ & $-0.53^{\mathrm{NS}}$ \\
RML0002 & $-0.13^{\mathrm{NS}}$ & $-0.27^{\mathrm{NS}}$ & $-0.95^{*}$ & $-0.32^{\mathrm{NS}}$ & $0.08^{\mathrm{NS}}$ & $0.73^{*}$ & $-0.41^{\mathrm{NS}}$ & $1.27^{* *}$ \\
RML0003 & $-0.47^{\mathrm{NS}}$ & $0.69^{*}$ & $-0.21^{\mathrm{NS}}$ & $-0.97^{*}$ & $1.80^{* *}$ & $-1.06^{*}$ & $-0.24^{\mathrm{NS}}$ & $0.46^{*}$ \\
RML0005 & $-0.15^{\mathrm{NS}}$ & $-0.90^{*}$ & $0.28^{\mathrm{NS}}$ & $0.58^{*}$ & $-0.10^{\mathrm{NS}}$ & $0.58^{*}$ & $0.83^{*}$ & $-1.12^{* *}$ \\
RML0018 & $-1.07^{* *}$ & $-1.08^{* *}$ & $-0.01^{\mathrm{NS}}$ & $2.09^{* *}$ & $-1.66^{* *}$ & $2.59^{* *}$ & $0.02^{\mathrm{NS}}$ & $-0.87^{*}$ \\
RML0014 & $-0.87^{\mathrm{NS}}$ & $1.16^{*}$ & $-0.75^{\mathrm{NS}}$ & $-0.30^{\mathrm{NS}}$ & $-0.20^{\mathrm{NS}}$ & $0.39^{\mathrm{NS}}$ & $-0.58^{\mathrm{NS}}$ & $1.17^{*}$ \\
RML0004 & $0.14^{\mathrm{NS}}$ & $-0.36^{\mathrm{NS}}$ & $-0.17^{\mathrm{NS}}$ & $0.93^{* *}$ & $-0.83^{*}$ & $-0.72^{*}$ & $0.91^{*}$ & $0.09^{\mathrm{NS}}$ \\
RML0015 & $0.05^{\mathrm{NS}}$ & $-0.72^{*}$ & $1.46^{* *}$ & $-0.74^{* * *}$ & $0.26^{\mathrm{NS}}$ & $-0.43^{\mathrm{NS}}$ & $0.48^{\mathrm{NS}}$ & $-0.36^{\mathrm{NS}}$ \\
RML0017 & $-0.31^{\mathrm{NS}}$ & $-0.15^{\mathrm{NS}}$ & $0.47^{\mathrm{NS}}$ & $-0.21^{\mathrm{NS}}$ & $1.76^{* *}$ & $-1.92^{* *}$ & $0.48^{\mathrm{NS}}$ & $-0.12^{\mathrm{NS}}$ \\
\hline
\end{tabular}

$* * *=$ Significant at $\mathrm{P}=0.001 ; * *=$ Significant at $\mathrm{P}=0.01 ; *=$ Significant at $\mathrm{P}=0.05 ; \mathrm{NS}=\mathrm{Not}$ significant $(\mathrm{P}>0.05)$ 
TABLE 9. Specific combining abilities for silking of nine female and eight male inbred maize lines in North Carolina Design II $(9 \times 8)$

\begin{tabular}{lccllllll}
\hline Parents & $\begin{array}{l}\text { RML } \\
0006\end{array}$ & $\begin{array}{l}\text { RML } \\
0007\end{array}$ & $\begin{array}{l}\text { RML } \\
0008\end{array}$ & $\begin{array}{l}\text { RML } \\
0009\end{array}$ & $\begin{array}{l}\text { RML } \\
0010\end{array}$ & $\begin{array}{l}\text { RML } \\
0013\end{array}$ & $\begin{array}{l}\text { RML } \\
0011\end{array}$ & $\begin{array}{l}\text { RML } \\
0012\end{array}$ \\
\hline RML0019 & $-2.43^{*}$ & $1.77^{*}$ & $-0.26^{\mathrm{NS}}$ & $3.66^{* *}$ & $-1.57^{\mathrm{NS}}$ & $-0.34^{\mathrm{NS}}$ & $-1.95^{*}$ & $1.13^{\mathrm{NS}}$ \\
RML0002 & $-2.24^{*}$ & $-2.05^{*}$ & $-1.07^{\mathrm{NS}}$ & $0.09^{\mathrm{NS}}$ & $-1.38^{*}$ & $1.59^{* *}$ & $5.24^{* *}$ & $-0.18^{\mathrm{NS}}$ \\
RML0003 & $1.85^{\mathrm{NS}}$ & $-1.95^{* * *}$ & $-1.23^{\mathrm{NS}}$ & $-2.06^{\mathrm{NS}}$ & $2.46^{*}$ & $0.19^{\mathrm{NS}}$ & $0.08^{\mathrm{NS}}$ & $0.66^{\mathrm{NS}}$ \\
RML0005 & $-1.96^{*}$ & $0.99^{*}$ & $0.46^{\mathrm{NS}}$ & $0.12^{\mathrm{NS}}$ & $0.90^{\mathrm{NS}}$ & $0.37^{\mathrm{NS}}$ & $-1.98^{*}$ & $1.10^{\mathrm{NS}}$ \\
RML0018 & $5.04^{* *}$ & $0.49^{\mathrm{NS}}$ & $-0.79^{\mathrm{NS}}$ & $0.12^{\mathrm{NS}}$ & -2.60 & $-0.38^{\mathrm{NS}}$ & $-0.73^{\mathrm{NS}}$ & $-1.15^{\mathrm{NS}}$ \\
RML0014 & 1.98 & $-2.83^{*}$ & $-0.85^{\mathrm{NS}}$ & $3.06^{* * *}$ & $1.84^{\mathrm{NS}}$ & $-2.44^{* * *}$ & $1.71^{\mathrm{NS}}$ & $-2.47^{*}$ \\
RML0004 & $-1.05^{\mathrm{NS}}$ & $3.64^{*}$ & $1.11^{\mathrm{NS}}$ & $-2.47^{*}$ & $0.56^{\mathrm{NS}}$ & $-1.97^{*}$ & $-1.33^{\mathrm{NS}}$ & $1.50^{\mathrm{NS}}$ \\
RML0015 & $-2.30^{*}$ & $0.64^{\mathrm{NS}}$ & $1.86^{*}$ & $-0.47^{\mathrm{NS}}$ & $1.81^{*}$ & $0.53^{\mathrm{NS}}$ & $-0.08^{\mathrm{NS}}$ & $-2.00^{*}$ \\
RML0017 & $1.11^{\mathrm{NS}}$ & $-0.70^{\mathrm{NS}}$ & $0.78^{\mathrm{NS}}$ & $-2.06^{*}$ & $-2.03^{* *}$ & $2.44^{*}$ & $-0.95^{\mathrm{NS}}$ & $1.41^{\mathrm{NS}}$
\end{tabular}

$* * *=$ Significant at $\mathrm{P}=0.001 ; * *=$ Significant at $\mathrm{P}=0.01 ; *=$ Significant at $\mathrm{P}=0.05 ; \mathrm{NS}=$ Not significant $(\mathrm{P}>0.05)$

\section{DISCUSSION}

Griffing'diallel method 4. The significant differences between crosses in a GDM4 design (Table 3) implies the existence of GCA and or SCA (Hallauer et al., 2010; Fasahat et $a l ., 2016)$ for both grain yield and silking. The GCA effects pertain to additive effects; while SCA relates to dominance effects (Williams $e t$ al., 2008). Usually, in diallel designs, SCA refers to non-additive effects because it includes, in addition to dominance effects, the three types of epistasis: additive $\times$ additive epistasis, additive $\times$ dominance epistasis and dominance $\times$ dominance epistasis (Singh and Roy, 2007; Chukwu et al., 2016; Nardino et al., 2016).

The significance of GCA for grain yield and silking (Table 3 ) implies the presence of additive effects for the two traits; whereas the significance of SCA for grain yield and the nonsignificance of GCA for silking shows the existence of non-additive effects for grain yield, and the absence of non-additive effects for silking. The ratio GCA/SCA was less than unit, for grain yield indicating the predominance of non-additive effects over additive effects in controlling the grain yield.
The proportion GCA/SCA was very large and significant $(\mathrm{P}=0.05)$ for silking, indicating the exclusive presence of additive effects in controlling silking. The predominance of nonadditive effects or the equal importance of additive and non-additive effects for controlling grain yield have been frequently reported in diallel design experiments (Glover et al., 2005; Singh and Roy, 2007; Karaya et al., 2009; Devi and Singh, 2011). The prevalence of additive effects for controlling silking has been reported as well in diallel experiments (Glover et al., 2005; Singh and Roy, 2007).

Our findings have clearly shown that grain yield is predominantly controlled by nonadditive effects over additive effects; while silking is exclusively controlled by additive effects. These results suggest that silking can be improved through recurrent selection (Cabral et al., 2015); whereas grain yield can be improved through methods combining recurrent selection and testcrossing procedures such as reciprocal recurrent selection (Gakunga et al., 2012).

The inbred line RM0014, had the highest GCA effect for grain yield (Table 4), hence, contributing to increasing this trait in the crosses, although it had a significant and 
positive GCA for silking. Positive GCAs for silking are not preferable because they increase the maturity period in the crosses (Aminu et al., 2014). In fact, maize breeding programmes aim at increasing significantly the grain yield and reducing the silking (Hallauer et al., 2010). Therefore, an inbred line with a positive GCA for grain yield and negative GCA for silking is preferable in breeding programmes (Varaprasad and Shivani, 2016).

Parents RML0018, RML0015 and RML0006, had positive and significant GCAs for grain yield (Table 4). Furthermore, they had negative and significant or non-significant GCAs for silking; therefore, presenting the best characteristics to be used in breeding programmes, as outlined by Hallauer et al. (2010). The three inbred lines, RML0014, RML0018 and RML0015, were developed from ISARM101; while RML0006 was generated from Ndaruhutse (Pool 32). Hence, it appears that additive effects for grain yield in population ISARM01 (NYA-1) are more important than in the two other populations from which parent lines were generated.

The lines with best GCA effects and crosses with best SCA effects can be used in predicting the best performing cultivars (Technow et al., 2012; Oliveira et al., 2016). Lines with best GCAs effects are best to predict synthetics; while the crosses with best SCAs are best for predicting hybrid varieties (Malik et al., 2004). Hence, the inbred lines: RML0014, RML0018, RML0015 and RML0006 will be usefull in future maize breeding programme in Rwanda and beyond to breed best synthetic varieties; while crosses: RML0004/RML0010, RML0010/RML0013, RML0002/RML0015, RML0018/RML0013, RML0003/RML0009 and RML0014/RML0010 will be usefull for developing new maize hybrid cultivars.

North Carolina Design II. The significant differences between crosses in the NCDII (Table 6) indicate the existence of GCA effects and or SCA effects for grain yield. In the analysis of variance of NCDII, the means squares of female parents pertains to GCA, the means squares of male parents indicate the GCA as well and the means squares of female parents $\times$ male parents interaction are related to the SCAs. There are two independent estimations of GCA that allow determination of the maternal effects indicated by the deference between GCA female parents and GCA male parents. The GCA of male parents is free from maternal effects and represents the real additive effects (Ngaboyisonga et al., 2008).

The GCAs of female and male parents were significant (Table 6), indicating the existence of additive effects for the two traits. Moreover, the ratio $\mathrm{GCA}_{\mathrm{FP}} / \mathrm{GCA}_{\mathrm{MP}}$ was not significant for grain yield, but significant for silking, implying absence of maternal effects for grain yield, but their presence for silking (Halluer et al., 2010; Fasahat et al., 2016). The maternal effects results from the influence of the female parent genotype on the phenotype of its offspring. These effects are different from cytoplasmic inheritance, which results from the inheritance controlled by extra-nuclear DNA (Wolf and Wade, 2009; Zhang et al., 2016). Narayanamma et al. (2013), using NCDII, also found the absence of maternal effects for grain yield of chickpea. Derera $e t$ al. (2008) found that maternal effects controlled grain yield and several secondary traits of maize under drought environments, unlike in optimal environments where grain yield was not controlled by these maternal effects. The existence of maternal effects influenced the choice of parent and the direction of making crosses in NCDII (Derera et al., 2008; Ngaboyisonga et al., 2009).

The significance of GCA of female and male parents and their ratio indicates that grain yield was controlled by additive effects; while silking was under the control of additive and maternal effects. Furthermore, the significance of SCAs for the two traits demonstrated that nonadditive effects were present as well. However, the ratio GCA/SCA was not significant for grain yield, indicating an equal importance of 
additive and non-additive effects; but was significant for silking demonstrating the predominance of additive effects over nonadditive effects.

The significance of sites $\times$ crosses, sites $\times$ female parents (sites $\times \mathrm{GCA}_{\mathrm{F}}$ ), sites $\times$ male parents $\left(\right.$ sites $\times \mathrm{GCA}_{\mathrm{M}}$ ) and sites $\times$ female parents $\times$ male parents (sites $\times$ SCA) for grain yield, and their non-significance for silking indicated that breeding for grain yield is complicated by these interactions and would be done in target environments (Derera et al., 2008).

The female inbred lines, RML0014 and RML0017, had high, positive and significant GCAs for grain yield and positive and significant GCA for silking (Table 7), implying that they increase grain yield in crosses and at the same time increase silking as well. Therefore, they have are useful for improving grain yield in crosses, but they have an undesirable effect of increasing silking (Hallauer et al., 2010, Ndhlela et al., 2015). Their use will depend primarily on the targeted trait, namely grain versus silking. The male inbred line, RML0010, had high GCA for grain yield and non-significant GCA for silking, hence, it had the necessary propriety for improving grain yield in the crosses and not affecting silking (Ndhlela et al., 2015).

Crosses: RML0019/RML006, RML0018/ RML0013, RML0018/RML0009, RML0017/ RML0010, RML0015/RML0008, RML0002/ RML0012， RML0014/RML0012 and RML0014/RML0007 had high SCAs for grain yield, negative or non-significant SCAs for silking indicating that they had the necessities to be included in maize hybrid development programme, targeting high grain yield and small silking.

The inbred lines with best GCAs for grain yield and or silking will be utilised in predicting and generating the best maize synthetic varieties (Technow et al., 2012; Oliveira et al., 2016); while the crosses with best SCAs will be used in maize hybrid development programs aiming at high yield and small silking period (Ndhlela et al., 2015).

\section{Grifing'Diallel Method 4 (GDM4) versus North Carolina Design II (NCDII)}

The utilisation of GDM4 and NCDII by studying the ratio $\mathrm{F}=\mathrm{GCA} / \mathrm{SCA}$ in has led to observe that grain yield is controlled by both additive and non-additive effects. However, the GDM4 has indicated that non-additive effects are predominant over additive effects. On the other hand, NCDII showed that both additive and non-additive effects bear equal importance in controlling grain yield. Consequently, GDM4 is more efficient in discriminating the importance of additive effects, compared to non-additive effects for grain yield. Additionally, the prevalence of non-additive effects over additive effects supports the concept of improving grain yield through methods combing recurrent selection and testcrossing procedures, such as reciprocal recurrent selection as suggested by Gakunga et al. (2015). In the same way, the study of the ratio $\mathrm{F}=\mathrm{GCA} / \mathrm{SCA}$ in GDM4 and NCDII has led to a conclusion that silking is under the control of additive effects; while the role of non-additive effects is less important or negligible, supporting the idea of improving slking through recurrent selection as proposed by Cabral et al. (2015). The use of NCDII in this study has shown that maternal effects were absent for grain yield; but present for silking and controlled the trait.

\section{CONCLUSION}

The conclusion for the two designs is that grain yield is under the control of additive and not additive and non-additive effects with the predominance of additive effects; but additive and maternal effects predominately control silking.

The utilisation of GD4 and NCDII has made possible to identify six inbred lines: RML0006, 
RML0014, RML0015, RML0018, RM0017 and RML0010 with high GCAs for grain yield and negligible GCAs for silking, which will be used in future maize breeding programme in Rwanda to breed best synthetic varieties. It has further helped identifying nine crosses: RML0002/RML0015, RML0003/RML0018, RML0004/RML0010, RML0018/RML0013, RML0010/RML0013, RML0019/RML0006, RML0019/RML0007, RML0003/RML0010, RML0018/RML0009, having SCAs superior to $1.5 \mathrm{t} \mathrm{ha}^{-1}$ for grain yield with negligible SCAs for silking that will be used to develop new maize hybrid cultivars.

\section{ACKNOWLEDGEMENT}

We thank the Government of Rwanda and the Alliance for a Green Revolution in Africa (AGRA) for financial support through the project 2013 PASS 027 titled: "Developing, disseminating and utilising high yielding and stress tolerant/resistant maize varieties for increasing maize productivity, enhancing food security and generating incomes for smallholder farmers in Rwanda. We also thank the management of Cyabayaga, Rubona and Bugarama stations for research facilities especially evaluation plots.

\section{REFERENCES}

Al-Naggar, A.M.M., Atta, M.M.M., Ahmed, M.A. and Younis, A.S.M. 2016. Heterosis and combining ability of maize (Zea mays L.) grain protein, oil and starch content and yield as affected by water Stress. Archives of Current Research International 4(4):115.

Aminu, D., Mohammed, S.G. and Kabir, B.G. 2014. Estimates of combining ability and heterosis for yield and yield Traits in maize population (Zea mays L.), under drought conditions in the Northern Guinea and Sudan Savanna zones of Borno State, Nigeria. International Journal of
Agriculture Innovations and Research 2(5):2319-1473.

Asfaliza, R., Rafii, M.Y., Saleh, G.O., Omar, O. and Puteh, A. 2012. Combining ability and heritability of selected rice varieties for grain quality traits. Australian Journal of Crop Science 6(12):1718-1723.

Assefa, T., Zeleke, H., Afriye, T. and Otyama, P. 2017. Line $\times$ tester analysis of tropical high land maize (Zea mays L.) inbred lines top crossed with three East African maize populations. American Journal of Plant Sciences 8: 126-136.

Cabral, P.D.S., Júnior, A.T.A., Viana, A.P., Vieira, H.D., Freitas, I.L.J., Vittorazzi, C. and Vivas, M. 2015. Combining ability between tropical and temperate popcorn. Australian Journal of Crop Science 9 (4):256-263.

Chukwu, S.C., Okporie, E.O., Onyishi, G.C., Ekwu, L.G., Nwogbaga, A.C. and Ede, N. V. 2016. Application of diallel analyses in crop improvement. Agriculture and Biology Journal of North America 7(2): 95106.

Derera, J., Tongoona, P., Vivek, B.S. and Laing, M.D. 2008. Gene action controlling grain yield and secondary traits in southern African maize hybrids under drought and non-drought environments. Euphytica 162: 411-422.

Devi, P. and Singh, N.K. 2011. Heterosis, molecular diversity, combining ability and their interrelationships in short duration maize (Zea mays L.) across the environments. Euphytica 178:71-81

DICKEY-john. 2017. Mini GAC®. Operator's manual. DICKEY-john. Auburn, Illinois, USA.

FAO. 2017. FAOSTAT database collections. Food and Agriculture Organization of the United Nations. Rome. Access date: 201712-18. URL: http://faostat.fao.org.

Fasahat, P., Rajabi, A., Rad, M.J. and Derera, J. 2016. Principles and utilization of combining ability in plant breeding. 
Biometrics \& Biostatistics International Journal 4(1):00085. DOI: 10.15406/ bbij.2016.04.00085.

Gakunga, J., Mugo, S., Njoroge, J. and Olubayo, F. 2012. Combining ability of maize inbred lines resistant to Chilo partellus (Swinhoe) in the mid-altitude environment of Kenya. Journal of Plant Breeding and Crop Science 4(10): 161168.

Glover, M.A., Willmot, D.B., Darrah, L.L., Hibbard, B.E. and Zhu, X. 2005. Diallel analyses of agronomic traits using Chinese and U.S. maize germplasm. Crop Science: 45:1096-1102.

Griffing, B. 1956. Concept of general and specific combining ability in relation to diallel crossing systems. Australian Journal of Biological Sciences 9:463-493.

Hallauer, A.R., Carena, M.J. and Miranda, J.B. 2010. Quantitative genetics in maize breeding. Springer, New York, USA. $663 \mathrm{pp}$.

Kamara, M.M., El-Degwy, I.S., Koyama, H. 2014. Estimation combining ability of some maize inbred lines using line $x$ tester mating design under two nitrogen levels. Australian Journal of Crop Science 8 (9):1336-1342.

Karaya, H., Njoroge, K., Mugo, S. and Nderitu, H. 2009. Combining ability among twenty insect resistant maize inbred lines resistant to Chilo partellus and Busseola fusca stem borers. International Journal of Plant Production 3(1):115-126.

Khattab, S.A.M., Mustafa, E.A.H., El-Enany, M.A.M. and da Siva, J.A.T. 2011. Combining ability for drought tolerance in maize (Zea mays L.) using line $\times$ tester analysis. International Journal of Plant Breeding 5(2):122-127.

Kumar, J., Singh, S.K., Singh, L., Kumar, M., Srivastava, M., Singh, J. and Kumar, A. 2017. Combining ability analysis for yield and its components in bread wheat (Triticum aestivum L.) under abiotic stress.
International Journal of Current Microbiology and Applied Sciences 6(3): 24-39.

Malik, S.I., Malik, H.N. Minhas, N.M. and Munir, M. 2004. General and specific combining ability studies in maize diallel crosses. International Journal of Plant Production 6(5):856-859.

Mason, R.L., Gunst, R.F and Hess, J.L. 2003. Statistical design and analysis of experiments, $2^{\text {nd }}$ Edition: With applications to engineering and science. John Wiley \& Sons, Inc., Hoboken, New Jersey, USA. 728pp.

Nahayo, A., Omondi, M.O., Zhang, X., Li, L., Pan, G. and Joseph, S. 2016. Factors influencing farmers' participation in crop intensification program in Rwanda. Journal of Integrative Agriculture 16(6):14061416.

Narayanamma, V.L., Gowda, C.L.L., Sriramulu, M., Ghaffar, M.A., Hari, C. and Sharma, H.C. 2013. Nature of gene action and maternal effects for pod borer, Helicoverpa armigera resistance and grain yield in chickpea, Cicer arietinum. American Journal of Plant Sciences 4:2637.

Nardino, M., Carvalho, I.R., Barros, W.S., de Souza, V.Q., da Rosa, T.C., Koch, F., Szareski, V.J., Aisenberg, G., Aumonde, T.Z., Pedó, T., Szareski, V.J. and Demari, G.H. 2016. Diallel cross analysis in maize. International Journal of Current Research 8 (8): 35686-35692.

Ndhlela, T., Herselman, L., Semagn, K., Magorokosho, C., Mutimaamba, C. and Labuschagne, M.K. 2015. Relationships between heterosis, genetic distances and specific combining ability among CIMMYT and Zimbabwe developed maize inbred lines under stress and optimal conditions. Euphytica 204:635-647.

Ngaboyisonga, C. 2003. Small-scale farmers benefit from CIMMYT germplasm in Rwanda. pp. 198-199. In: Book of 
Abstracts. Arnel R. Hallauer International Symposium on Plant Breeding, 17-22 August 2003; edited by CIMMYT, Mexico City, Mexico, Mexico, D.F.

Ngaboyisonga, C., Njoroge, K., Kirubi, D. and Githiri, S.M. 2008. Effects of field conditions, low nitrogen and drought on genetic parameters of protein and tryptophan concentrations grain of quality protein maize. International Journal of Plant Production 2(2):137-152.

Ngaboyisonga, C., Njoroge, K., Kirubi, D. and Githiri, S.M. 2009. Effects of low N and drought on genetic parameters of grain yield and endosperm hardness of quality protein maize. Asian Journal of Agricultural Research 3(1):1-10.

Ngaboyisonga, C., Nizeyimana, F., Nyombayire, A., Gafishi, M.K., Ininda, J. and Gahakwa, D. 2014. Identification of elite, high yielding and stable maize cultivars for Rwandan mid-altitudes environments. pp. 165-175. In: Challenges and opportunities for agricultural intensification of the humid highland systems of Sub-Saharan Africa. Vanlauwe, B., van Asten, P. and Blomme, G. (Eds.). Springer International Publishing, Switzerland.

Oliveira, G.H.F., Buzinaro, R. and Revolt, L.T.M. 2016. An accurate prediction of maize crosses using diallel analysis and best linear unbiased predictor (BLUP). Chilean Journal of Agricultural Research 76 (3): 294-295.

Payne, R., Murray, D., Harding, D.B. and Soutar, D. 2011. Introduction to GenStat ${ }^{\circledR}$ for Windows ${ }^{\mathrm{TM}} 14^{\text {th }}$ Edition. VSN International, Hemel Hempstead, Hertfordshire, UK.

Salami, A.E. Ogbowuro, G.O. 2016. Gene action and heritability estimates of grain yield and disease incidence traits of low-N maize (Zea mays L.) inbred iines. Agriculture and Biology Journal of North America 7(2):50-54.
SAS Institute Inc. 2011. SAS/STAT ${ }^{\circledR} 9.3$ User’s Guide. SAS Institute Inc., Cary, North Carolina, USA.

Shalabh, H.T. 2009. Statistical analysis of designed experiments. $3^{\text {rd }}$ Edition. Springer, New York, USA. 615pp.

Singh, P.K. and Roy, A.K. 2007. Diallel analysis of inbred lines in maize (Zea mays L.). International Journal of Agriculture and Crop Sciences 3(1): 213-216.

Technow, F., Riedelsheimer, C. Schrag, T.A. and Melchinger, A.E. 2012. Genomic prediction of hybrid performance in maize with models incorporating dominance and population specific marker effects. Theoretical and Applied Genetics 125:1181-1194.

Terres, L.R., Lenz, E.A., Rocha, D., Cerioli, M. and Pereira, A.S. 2017. Combining ability of potato parents for tuber appearance and tuber yield component traits. Crop Breeding and Applied Biotechnology 17: 99-106.

Varaprasad, B.V. and Shivani, D. 2016. Combing ability studies for yield and its attributing characters in maize (Zea mays L.) over environments. International Journal of Advanced Biological Research 6(2):300-305.

Williams, W.P., Windham, G.L. and Buckley, P.M. 2008. Diallel analysis of aflatoxin accumulation in maize. Crop Science 48: 134-138.

Wolf, J.B. and Wade, M.J. 2009. What are maternal effects (and what are they not)? Philosophical Transactions of the Royal Society B 364:1107-1115.

Zhang, X., Hirsch, C.N., Sekhon, R.S., de Leon, N. and Kaeppler, S.M. 2016. Evidence for maternal control of seed size in maize from phenotypic and transcriptional analysis. Journal of Experimental Botany 67(6): 1907-1917.

Zhang, Y. and Kang, M.S. 2003. DIALLELSAS: A program for Griffing's diallel methods. pp 1-19. In: Handbook of 
formulas and software for plant geneticists and breeders; edited by Kang, M.S., The Haworth Press, Inc. New York, USA.

Zhang, Y. and Kang, M.S. 1997. DIALLELSAS: A program for Griffing's diallel methods. Agronomy Journal 89:176-182.
Zhang, Z., Kang, M. S. and Lamkey, K.R. 2005. DIALLEL-SAS05: A comprehensive Program for Griffing's and GardnerEberhart Analyses. Agronomy Journal 97:1097-1106. 